\title{
Multi Criteria Decisions Making approach to choose 'Integrators' in Malaysian local broiler industry
}

\author{
Hendrik Lamsali and Ahmad Shabudin Ariffin \\ School of Technology Management and Logistics,Universiti Utara Malaysia, Kedah, Malaysia
}

\begin{abstract}
The Malaysian broiler industry is an integral component of the agriculture sector that generates sustainable food supplies to almost 30 million populations in the country. The industry comprises of conventional and commercial farms for which the latter is more sustainable with contract farming schemes and involvement of major integrators and growers. The survival of local growers as one of the important players within broiler's supply chain hierarchy is largely depending on the integrators. Hence, this study aims to identify important factors that local growers consider when selecting their integrators. Specifically, the objectives are to prioritize integrators' selection factors and to determine the critical ranking of each factor that will be beneficial to the local growers. A MCDM approach in the form of Analytical Hierarchy Process (AHP) is employed to evaluate and rank the importance of the said factors based on inputs from selected broilers' representatives. Five main criteria are considered in the AHP analysis that include relationships, reliability, logistics, input and price. The result indicates that reliability had the highest priority, followed by pricing factor, input criteria, relationships with the integrator, and finally the logistics facility. For overall sub-criteria, supplied quantity is ranked number one, followed by price of raw materials, availability of dayold chick, quality conformance, technology sharing, and in-house logistics facility. At the end of the study, future research avenues are suggested.
\end{abstract}

\section{Introduction}

The Malaysian broiler industry is an important part of the agriculture sector providing employment and producing useful animal protein food for the population, estimated at 28 million people and also to about 4 million people in Singapore. According to Ali (2003), Malaysia has one of the highest per capita consumption of chicken in the world. Broiler industry in Malaysia comprises of commercial farms and conventional farms; commercial farms that run business on contract farming basis with integrator and conventional farms that belong to independent entrepreneurs. According to Ariffin, Lamsali and Mohtar (2012), the contracting scheme is therefore more likely to sustain. In 2009 there were 3,300 farms in operation carrying a standing population of nearly 186 million broiler chickens. Of these farms, $22.9 \%$ are large farms with more than 50,000 broilers per cycle. Ariffin, Lamsali and Mohtar (2013) also highlighted that the states of Johor, Sarawak and Perak alone were producing $52 \%$ of total national production. For local broiler industry, main players normally have a vertical integrated supply chain as well as operating as an integrated producer. Two parties in a typical contract farming arrangement include the grower and the company (Integrator). Integrators recruit growers to rear broiler chickens for meat based on a predetermined contractual guideline. This contract farming scheme is also helping the growers to mitigate risks related to fluctuations of input prices and provide a secure market demand for their product. Most integrators in Malaysia participated in contract farming with growers for broiler production. Hence, the integrators are always actively involved in almost every stage of production. While the important role of integrators is well documented, empirical evidence suggesting which factor to consider when selecting integrators remain limited and inconclusive. The need to identify and to prioritize integrators' selection factors is timely to both growers and integrators. It is a high time for relevant parties such as the integrators to understand the 'survival' need of the growers and to seek further improvement. Hence, the objective of this study is to determine factors that are critical when selecting potential integrators. In particular, the study aims to prioritize and rank the criteria (selection factors) using the Analytical Hierarchy Process (AHP) method. The remaining part of this paper is organized as follows: Section 2 presents overview of the current broiler industry followed by Section 3 on the AHP method and Section 4 on the determination of the main criteria and sub-criteria. Section 5 discloses the computational works in which the results and 
sensitivity analysis are discussed. Finally, Section 6 concludes the paper with discussion and recommendation of the study.

\section{The Broiler Industry}

Broiler contracting involves the use of improved and standardized technology and production practices. This involves supply of inputs, close contact and training of the contract grower. Main players normally have a vertically integrated supply chain, operating as integrated producer, owning the majority of all breeding, feed, slaughtering and processing facilities as well as operate with a wide variety of distribution channels, ranging from super and hyper markets to distributors, restaurants, wet markets and groceries. Vertical production chains consist of a single company controlling all aspects of each stage of production. Hatcheries, farms, feed companies processing plants, harvesting team, distribution, and markets can all be integrated into a single corresponding supply system. Many producers are shifting their production further into these types of vertical systems. In Malaysia, there are some concerns of a few large integrated systems controlling the broiler sector.

The term "contract farming" generally refers to situations in which a farmer raises or grows an agricultural product for a vertically integrated corporation. There are two parties in a typical contract farming arrangement: the grower and the company (Integrator). Broiler contracts consist of outsourcing the growing stage. Integrators recruit large farms (growers) to rear broiler chickens for meat according to contractual guidelines. Farming contracts can also help growers mitigate risks posed by fluctuations of input prices and provide a secure market outlet for their product. The latter is especially important because of the limited facilities that process chickens raised by independent farmers. While current trends are moving producers toward vertical integration, there remain many farms currently under contract or with unused infrastructure from past contracts. Most integrators in Malaysia participate in contract farming with growers for broiler production. Coordinating mechanisms along a vertical supply chain include contracts and integrated ownership and operation. Vertical agreements may either foster competition by generating efficiency gains, or they may inhibit competition through vertical market foreclosure or by facilitating collusive activities at any level of the supply chain (Vaidya, Omkarprasad and Kumar, 2006).

\section{The AHP Method}

The Analytical Hierarchy Process (AHP) is a multicriteria decision making method developed by Thomas L. Saatyin 1970s. One can refer to many of his previous studies on hierarchies, prioritization of decision making factors and the AHP method (Saaty, 1979; Saaty, 1990; Saaty, 1994; Saaty, 2000; Saaty,
2008). The method has been used extensively in many different sectors such as government, manufacturing, services, engineering and management (Opasanon, Santhaporn and Lertsanti, 2013). According to Vaidya et al., (2006), AHP has been widely employed to decision making in areas such as resource allocation planning. It was also pointed out by Sipahi and Timor (2010) that manufacturing sector had been the biggest user of the AHP method. The applications of AHP method in agribusiness was illustrated by Sigueira, da Silva and Aguiar (2008) in which the method had been used to rank the commodities in terms of the feasibility prospects with the intention of introducing milk futures contracts in Brazil. Study by Garcia, Almeida, Caldara, Naas, Pereira and Ferreira (2012) investigated the usage of AHP for selecting the most suitable bedding material for broiler production in Brazil. In Indonesia, Febransyah and Simangunsong (2015) had examined supply chain competitiveness in local food industry using a combination of the AHP and ANP methods. In the meantime, Yakovleva, Sarkis and Sloan (2012) had used AHP method to determine importance ratings and overall index of sustainability of food supply chains. Hitherto, there had been very limited applications of the AHP-related methods in livestock or poultry industry. This research utilized both primary and secondary data collection methods to get insight into the broiler industry. Primary data were gathered from interviews with four senior officers from local growers with positions ranging from managing director to chief business officer. Special briefing to all selected respondents had been conducted prior to the fulfillment of the questionnaire. The pairwise comparisons were developed based on key information in the secondary data and input from an experienced chief business officer of a local grower. Table 1 depicts the measurement scale that is used in this study and is adopted from Saaty (2000).

Table 1: Measurement scales of the level of importance

\begin{tabular}{|l|l|l|}
\hline $\begin{array}{l}\text { Importance } \\
\text { Level }\end{array}$ & Denotation & \multicolumn{1}{c|}{ Definition } \\
\hline 1 & $\begin{array}{l}\text { Equally } \\
\text { preferred }\end{array}$ & $\begin{array}{l}\text { Both factors in } \\
\text { consideration are of } \\
\text { equal importance }\end{array}$ \\
\hline 3 & $\begin{array}{l}\text { Moderately } \\
\text { more } \\
\text { preferred }\end{array}$ & $\begin{array}{l}\text { Experience and } \\
\text { judgement shows a } \\
\text { slightly more } \\
\text { preference of one } \\
\text { factor than the other }\end{array}$ \\
\hline 5 & $\begin{array}{l}\text { Strongly more } \\
\text { preferred }\end{array}$ & $\begin{array}{l}\text { Experience and } \\
\text { judgement strongly } \\
\text { favor one factor over } \\
\text { another }\end{array}$ \\
\hline 7 & $\begin{array}{l}\text { Very strongly } \\
\text { more } \\
\text { preferred }\end{array}$ & $\begin{array}{l}\text { An activity is favored } \\
\text { very strongly over } \\
\text { another; its } \\
\text { dominance } \\
\text { demonstrated in } \\
\text { practice }\end{array}$ \\
\hline
\end{tabular}




\begin{tabular}{|l|l|l|}
\hline 9 & $\begin{array}{l}\text { Extremely } \\
\text { more } \\
\text { preferred }\end{array}$ & $\begin{array}{l}\text { The evidence } \\
\text { favoring one activity } \\
\text { over another is of the } \\
\text { highest possible } \\
\text { order of affirmation }\end{array}$ \\
\hline $2,4,6,8$ & $\begin{array}{l}\text { Intermediate } \\
\text { values }\end{array}$ & $\begin{array}{l}\text { When compromise is } \\
\text { needed Judgments } \\
\text { can reveal an evenly } \\
\text { matched preference } \\
\text { between the levels of } \\
\text { importance }\end{array}$ \\
\hline
\end{tabular}

Source: Saaty (2000)

The AHP method is based on three key steps in which are (1) decomposition, (2) comparative judgment, and (3) synthesis of priorities (Korpela and Tuominen, 1996). The first step involves breaking down problem and creating hierarchical structure of several elements. The hierarchy comprises of goal, criteria, sub-criteria and alternatives. The second step is to determine the relative importance of each element via pairwise comparison. Then, the third step is to assess the composite weight of each decision alternative (Opasanon, Santhaporn and Lertsanti, 2013). Figure 1 shows the AHP procedural steps as highlighted by Saaty (2000):

The summary of the steps to carry out the AHP method is as follows:

1. Develop the hierarchy of the problem comprising of the decision goal, the alternatives, and the criteria for evaluating the alternatives.

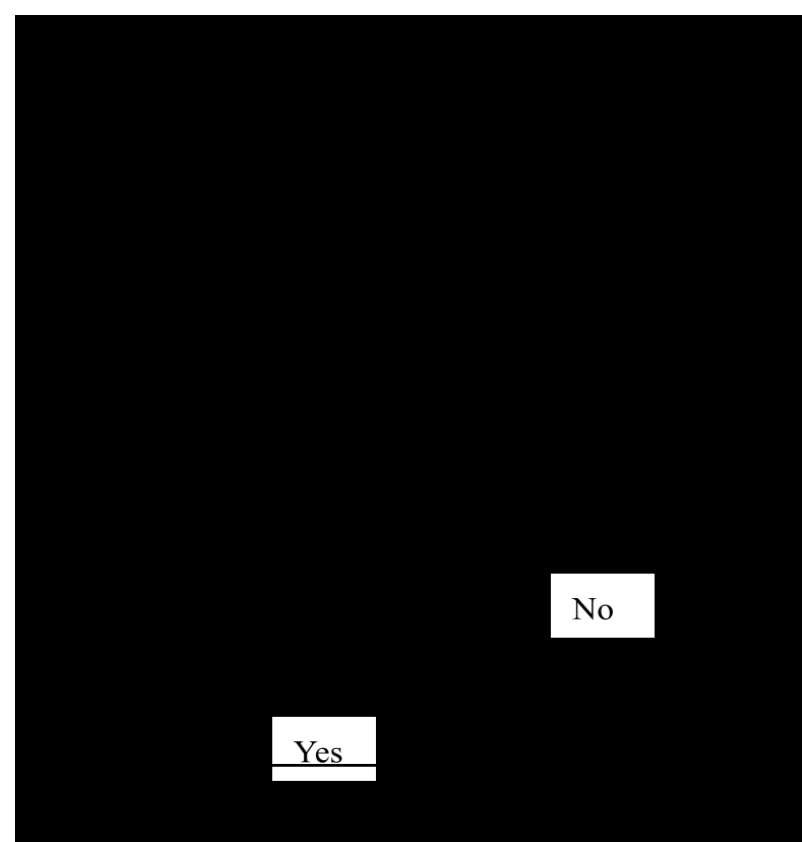

Fig.1. The analytic hierarchy process algorithm

2. Establish priorities among the elements of the hierarchy by using the pairwise comparisons analysis. Hence, pairwise comparison matrix should be developed for each decision alternative for each criterion.
3. Synthesize these judgments to generate set of overall priorities for the hierarchy. This can be done by computing the normalized matrix, followed by developing the preference vector, determining overall score for each decision alternative, and finally rank the decision alternatives.

4. Check the consistency of the judgments. This can be done by determining the degree of consistency for the pairwise comparisons in the decision criteria matrix using the following formula:

$$
\frac{C I}{R I}<0.1
$$

Where $\mathrm{CI}=$ Consistency Index and $\mathrm{RI}=$ Random Index

\begin{tabular}{|l|l|l|l|l|l|l|l|l|l|l|}
\hline $\begin{array}{l}\text { Attrib } \\
\text { utes }\end{array}$ & 1 & 2 & 3 & 4 & 5 & 6 & 7 & 8 & 9 & 10 \\
\hline RI & 0 & 0 & $\begin{array}{l}0 . \\
52\end{array}$ & $\begin{array}{l}0 . \\
39\end{array}$ & $\begin{array}{l}1 . \\
11\end{array}$ & $\begin{array}{l}1 . \\
25\end{array}$ & $\begin{array}{l}1 . \\
35\end{array}$ & $\begin{array}{l}1 . \\
40\end{array}$ & $\begin{array}{l}1 . \\
45\end{array}$ & $\begin{array}{l}1 . \\
49\end{array}$ \\
\hline
\end{tabular}

5. Make a final decision. In overall steps or stages to be followed for determining priorities and the best alternative are shown in the following Figure 2.

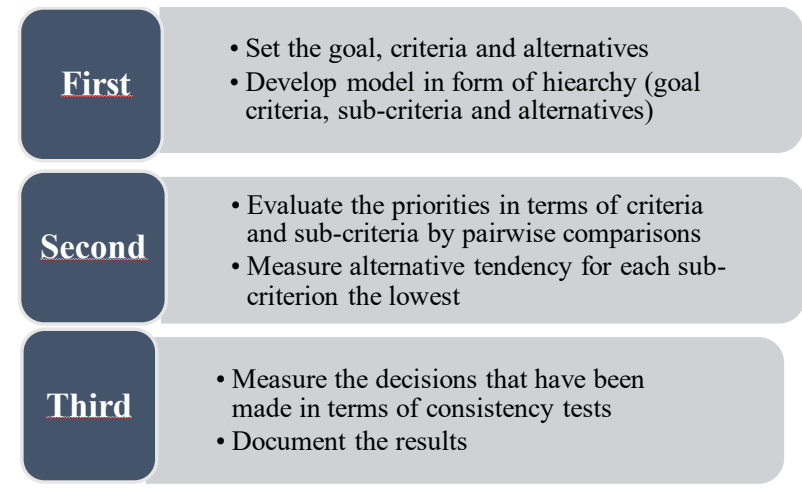

Fig. 2: Steps used in this study for prioritising alternatives

\section{Determination of main and sub- criteria}

Two approaches had been employed to determine main and sub-criteria that growers consider when selecting local integrators. First, secondary data gathering from relevant articles and journals were carried out in which relevant factors for selection of integrators had been identified. Then, an interview with a chief business officer from a local grower establishment had been conducted to further verify the aforementioned factors and to determine important criteria and the sub-criteria. The following Figure 3 illustrates the main criteria and the sub-criteria. Table 2 defines the operational definition for all criteria. 


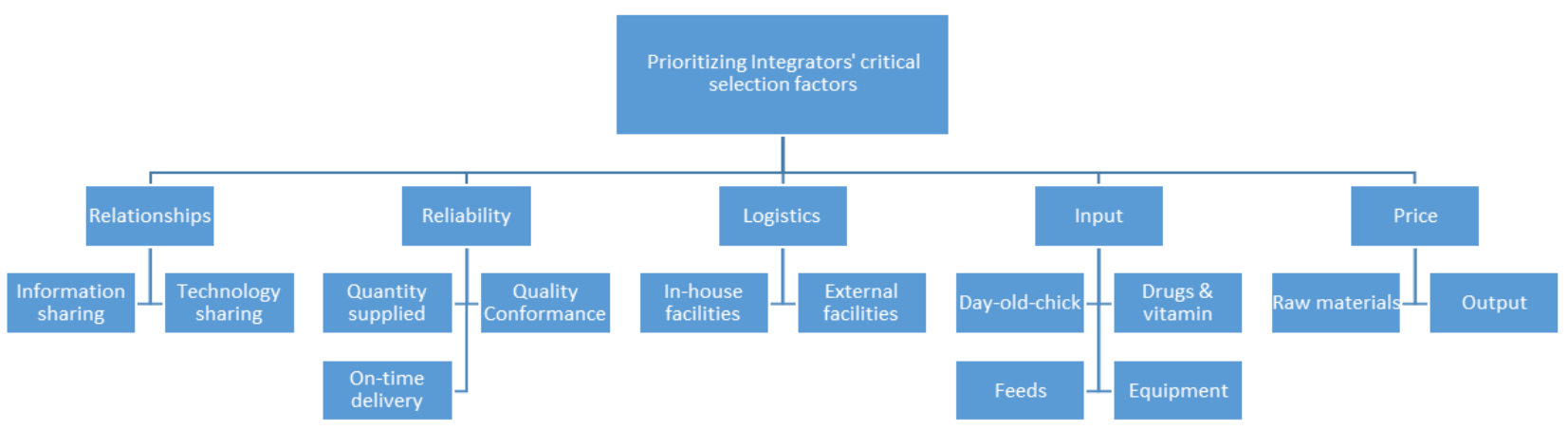

Fig. 3: Hierarchy of main and sub-criteria

Table 2: Definitions of the criteria and the sub-criteria

\begin{tabular}{|c|c|c|}
\hline No & $\begin{array}{l}\text { Criteria/Sub- } \\
\text { criteria }\end{array}$ & Definition \\
\hline 1 & Relationships & $\begin{array}{l}\text { The extent of which integrator } \\
\text { is willing to foster closer } \\
\text { relationships with the grower } \\
\text { in terms of sharing of } \\
\text { information and technology }\end{array}$ \\
\hline 2 & Reliability & $\begin{array}{l}\text { Measured by how reliable is } \\
\text { the integrator in terms of } \\
\text { quality conformance, accuracy } \\
\text { of quantity order fulfillment } \\
\text { and on-time delivery }\end{array}$ \\
\hline 3 & Logistics & $\begin{array}{l}\text { Refer to whether Integrator has } \\
\text { available in-house logistics } \\
\text { facilities or external } 3^{\text {rd }} \text { party } \\
\text { logistics (3PL) }\end{array}$ \\
\hline 4 & Input & $\begin{array}{l}\text { Relevant input factors of } \\
\text { which are offered in the form } \\
\text { of chicks, drugs and vitamin, } \\
\text { type of feeds, and equipment. }\end{array}$ \\
\hline 5 & Price & $\begin{array}{l}\text { Price of the raw materials } \\
\text { (input from integrator) and } \\
\text { output (buyback price) }\end{array}$ \\
\hline 6 & $\begin{array}{l}\text { Information } \\
\text { sharing }\end{array}$ & $\begin{array}{l}\text { Willingness of the integrator to } \\
\text { share relevant information with } \\
\text { the grower }\end{array}$ \\
\hline 7 & $\begin{array}{l}\text { Technology } \\
\text { sharing }\end{array}$ & $\begin{array}{l}\text { Willingness of the integrator to } \\
\text { share the technology and assist } \\
\text { the grower how to use them }\end{array}$ \\
\hline 8 & $\begin{array}{l}\text { Quantity } \\
\text { supplied }\end{array}$ & $\begin{array}{l}\text { Ability of the integrator to } \\
\text { supply to grower's demand in } \\
\text { terms of quantity }\end{array}$ \\
\hline 9 & $\begin{array}{l}\text { Quality } \\
\text { conformance }\end{array}$ & $\begin{array}{l}\text { Ability of the integrator to } \\
\text { supply quality inputs based on } \\
\text { predetermined standards }\end{array}$ \\
\hline 10 & $\begin{array}{l}\text { On-time } \\
\text { delivery }\end{array}$ & $\begin{array}{l}\text { Ability of the integrator to } \\
\text { deliver grower's orders on- } \\
\text { time }\end{array}$ \\
\hline 11 & $\begin{array}{l}\text { In-house } \\
\text { facilities }\end{array}$ & $\begin{array}{l}\text { Capability of the integrator to } \\
\text { provide in-house logistics }\end{array}$ \\
\hline
\end{tabular}

\begin{tabular}{|c|l|l|}
\hline 12 & $\begin{array}{l}\text { External } \\
\text { facilities }\end{array}$ & $\begin{array}{l}\text { support and facilities to the } \\
\text { grower }\end{array}$ \\
\hline 13 & $\begin{array}{l}\text { Integrator favors the usage of a } \\
3^{\text {rd }} \text { party logistics provider to } \\
\text { deliver grower's orders }\end{array}$ \\
\hline 14 & $\begin{array}{l}\text { Drugs } \\
\text { vitamins }\end{array}$ & $\begin{array}{l}\text { Ability of the integrator to } \\
\text { supply a day-old chick' to the } \\
\text { grower }\end{array}$ \\
\hline 15 & Feeds & $\begin{array}{l}\text { Types of drugs and vitamins } \\
\text { that the integrator use to breed } \\
\text { chicks }\end{array}$ \\
\hline 16 & Equipment & $\begin{array}{l}\text { Integrator's types of feeds } \\
\text { given to the chicks }\end{array}$ \\
\hline 17 & $\begin{array}{l}\text { Types of equipment and } \\
\text { technology that integrator used } \\
\text { to breed chicks } \\
\text { price materials }\end{array}$ & $\begin{array}{l}\text { The price of chicks and other } \\
\text { relevant raw materials the } \\
\text { grower has to pay }\end{array}$ \\
\hline 18 & Output price & $\begin{array}{l}\text { The buyback price the } \\
\text { integrator is willing to pay to } \\
\text { the grower }\end{array}$ \\
\hline
\end{tabular}

Table 3: Weights and priorities of each criteria

\begin{tabular}{|l|c|c|c|c|c|c|}
\hline & \multicolumn{7}{|c|}{ Weight of each main criteria with respect to } \\
& \multicolumn{7}{|c|}{ the Goal } \\
\hline Respondent & P1 & P2 & P3 & P4 & average & Rank \\
& & & & & & \\
$\begin{array}{l}P \\
\text { Criteria }\end{array}$ & & & & & & \\
\hline Relationships & 0.468 & 0.044 & 0.04 & 0.0 & 0.098 & $\mathbf{4}$ \\
& & & 5 & 61 & & \\
\hline Reliability & 0.222 & 0.458 & $\begin{array}{c}0.44 \\
1\end{array}$ & $\begin{array}{c}0.3 \\
58\end{array}$ & 0.406 & $\mathbf{1}$ \\
\hline Input & 0.147 & 0.127 & 0.18 & 0.1 & 0.168 & $\mathbf{3}$ \\
& & & 6 & 40 & & \\
\hline Price & 0.075 & 0.291 & 0.24 & 0.3 & 0.232 & $\mathbf{2}$ \\
& & & 6 & 51 & & \\
\hline Logistics & 0.089 & 0.079 & 0.08 & 0.0 & 0.096 & $\mathbf{5}$ \\
& & & 3 & 91 & & \\
\hline
\end{tabular}




\section{The Computational Works}

The analysis had been conducted using decision making software, the Expert Choice. For the pairwise comparisons, purposive sampling was employed. Input from four (4) important respondents were gathered and analyzed. The selected respondents were key representatives from four different local growers. Geometric means were then calculated to determine group judgment. At the end of the analysis, consistency test was carried out. The result in Table 3 indicate that reliability had been given the highest priority followed by pricing factor, input criteria, relationships with the integrator, and finally the logistics facility. Both reliability and pricing factors were dominantly important, accountable for $63.8 \%$ from overall weight with respect to the goal. The least important factor was the logistics. For the overall sub-criteria, Table 4 show that reliability in terms of supplied quantity had been ranked number one, followed by price of raw materials, availability of day-old chick, quality conformance, technology sharing, and in-house logistics facility. The bottom half of the ranking saw on-time delivery made it as the seventh important sub-criteria, followed by type of feeds, buyback price, information sharing, drugs and vitamins, the equipment used, and finally the $3^{\text {rd }}$ party logistics provider. The results show that reliability in terms of quantity supplied, the price of raw materials, and availability of day-old chick are the top three most important factors that growers consider when selecting integrators. Quality conformance, technology sharing and in-house logistics facility made up the next three high prioritized factors. At the other end, external $3^{\text {rd }}$ party logistics provider, type of equipment used, and type of drugs and vitamins had been ranked as the three least important factors by the growers.

Overall inconsistency for decision maker $\mathrm{P} 1$ is $0.08, \mathrm{P} 2$ is $0.07, \mathrm{P} 3$ is $0.08, \mathrm{P} 4$ is 0.09 , while for the group judgment (combined geometric mean) the inconsistency is 0.05 . In the meantime, sensitivity analysis had been carried out to measure how changes in certain criteria or decision maker's priority influence the prioritization of other criterion or the alternatives hierarchy. Using the Expert Choice software, both performance and dynamic sensitivity analysis had been performed. Figure 4 and Figure 5 below illustrated the hierarchy and the prioritization order. Figure4 illustrated the weights and the prioritization order of each sub-criterion with respect to the main criterion. In Figure 5, it is highlighted that technology sharing, quantity supplied, availability of day-old chick, inhouse logistics facility, and raw materials prices were given the highest weights for each main criteria. Nonetheless, the prioritization order may change upon changes in decision makers' preferences.

If closer relationships with integrator is given the highest priority (let assumes an increase of $21.3 \%$ for the weight of the relationships criteria from $9.8 \%$ to $31.1 \%$ ), then technology sharing becomes a number two alternative closely behind quantity supplied but way ahead of other factors. Technology sharing will become the most important alternative if the weight of the relationships factor increases to more than $32 \%$. Had a decision maker given more priority to the input factor, the prioritization order will change accordingly. For instance, an increase of weight for the input factor from $16.8 \%$ to $35.9 \%$ will push the availability of dayold chick into the summit of the prioritization order. Performance sensitivity analysis had indicated that when the price factor increases from $23.2 \%$ to $40 \%$, the price of raw materials becomes the most important factor in the prioritization ranking, followed by quantity supplied and output prices. However, it is also worth noting that only with substantial changes in one criteria or decision maker's priority can affect the prioritization order.

Table 4: Synthesized results of sub-criteria

\begin{tabular}{|c|c|c|c|c|c|c|}
\hline & \multicolumn{6}{|c|}{$\begin{array}{l}\text { Synthesized results with respect to the } \\
\text { Goal }\end{array}$} \\
\hline & $\mathrm{P} 1$ & P2 & P3 & P4 & $\begin{array}{l}\text { Aver } \\
\text { age* }\end{array}$ & $\begin{array}{l}\text { Ra } \\
\text { nk } \\
\end{array}$ \\
\hline $\begin{array}{cl}\text { Relationships } \\
\bullet \quad \text { Information } \\
\quad \text { sharing } \\
\text { • } \quad \text { Technology } \\
\quad \text { sharing }\end{array}$ & $\begin{array}{c}0.7 \\
1 \\
0.1 \\
0\end{array}$ & $\begin{array}{c}0.00 \\
6 \\
0.02 \\
9\end{array}$ & $\begin{array}{l}0.0 \\
07\end{array}$ & $\begin{array}{l}0.0 \\
08 \\
0.0 \\
41\end{array}$ & $\begin{array}{l}0.033 \\
0.065\end{array}$ & $\begin{array}{l}10 \\
5\end{array}$ \\
\hline $\begin{aligned} \text { Reliability } & \\
\bullet & \text { Quantity } \\
& \text { supplied } \\
\bullet & \text { On-time } \\
& \text { delivery } \\
\bullet \quad & \text { Quality } \\
& \text { conformance }\end{aligned}$ & $\begin{array}{l}0.2 \\
96 \\
0.0 \\
80 \\
0.0 \\
55\end{array}$ & $\begin{array}{c}0.30 \\
5 \\
\\
0.06 \\
7 \\
0.11 \\
6\end{array}$ & $\begin{array}{l}0.0 \\
53\end{array}$ & $\begin{array}{c}0.2 \\
39 \\
0.0 \\
46\end{array}$ & $\begin{array}{l}0.271 \\
0.058 \\
0.092\end{array}$ & $\begin{array}{l}1 \\
7\end{array}$ \\
\hline 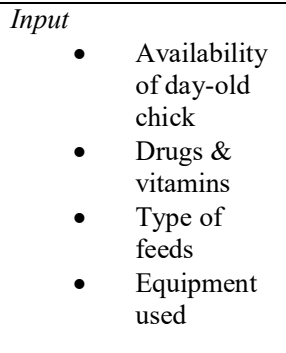 & $\begin{array}{l}0.1 \\
22 \\
0.0 \\
48 \\
\\
0.0 \\
32 \\
0.0 \\
17\end{array}$ & $\begin{array}{c}0.08 \\
5 \\
\\
0.01 \\
8 \\
\\
0.04 \\
9 \\
0.01 \\
5\end{array}$ & $\begin{array}{c}0.0 \\
48 \\
0.0 \\
17\end{array}$ & $\begin{array}{l}0.0 \\
93 \\
0.0 \\
27 \\
\\
0.0 \\
44 \\
0.0 \\
14\end{array}$ & $\begin{array}{l}0.112 \\
0.032 \\
0.047 \\
0.018\end{array}$ & $\begin{array}{c}3 \\
\\
11 \\
\\
8 \\
12\end{array}$ \\
\hline $\begin{aligned} & \text { Price } \\
& \bullet \text { Raw } \\
& \text { materials } \\
& \bullet \begin{array}{l}\text { Output } \\
\text { (buyback) }\end{array} \\
&\end{aligned}$ & $\begin{array}{c}0.1 \\
69 \\
0.0 \\
19 \\
\end{array}$ & $\begin{array}{c}0.19 \\
4 \\
0.04 \\
9\end{array}$ & $\begin{array}{c}0.1 \\
55 \\
0.0 \\
77 \\
\end{array}$ & $\begin{array}{c}0.2 \\
34 \\
0.0 \\
78 \\
\end{array}$ & $\begin{array}{l}0.154 \\
0.040\end{array}$ & $\begin{array}{l}2 \\
9\end{array}$ \\
\hline $\begin{array}{cl}\text { Logistics } & \\
\bullet & \text { In-house } \\
& \text { facilities } \\
\bullet & \text { External 3PL }\end{array}$ & $\begin{array}{c}0.0 \\
70 \\
0.0 \\
09\end{array}$ & $\begin{array}{c}0.05 \\
3 \\
\\
0.01 \\
3 \\
\end{array}$ & $\begin{array}{c}0.0 \\
52\end{array}$ & $\begin{array}{l}0.0 \\
60 \\
0.0 \\
12 \\
\end{array}$ & $\begin{array}{l}0.064 \\
0.014\end{array}$ & $\begin{array}{c}6 \\
13\end{array}$ \\
\hline
\end{tabular}

*the average is calculated using geometric mean formula 


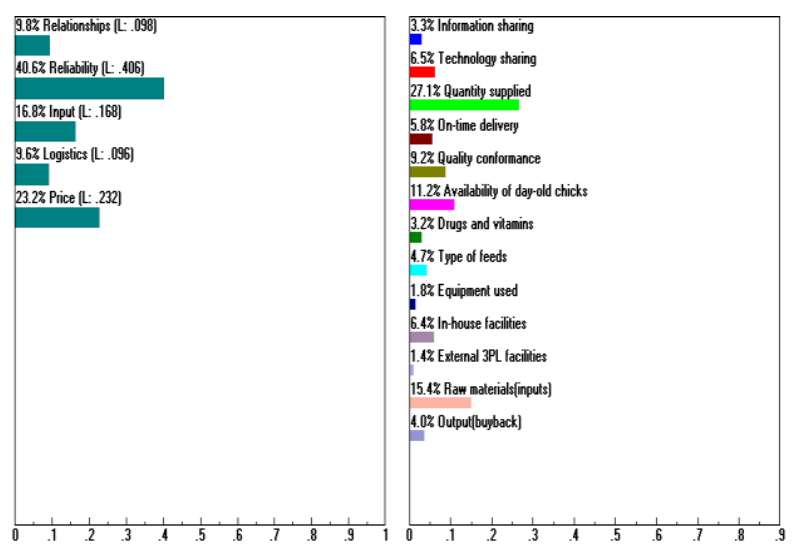

Fig. 4. Dynamic sensitivity analysis for the criterion and sub-criterion

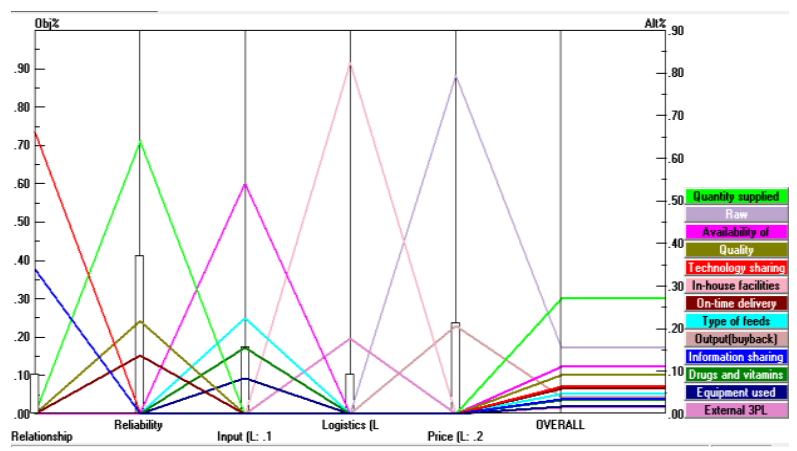

Fig. 5. Performance sensitivity analysis for the criterion and sub-criterion

\section{Conclusion and The Way Forward}

The study aims to facilitate local growers' selection of integrators by determining and prioritizing relevant important factors. Selecting competent and reliable integrators is crucial to the survival of growers in which one is expected to assist the latter in terms of raw materials, equipment and technology, feeding and hatchery, logistics and other support services. The findings show that reliability, followed by price had been given the highest priority when selecting potential integrators. Apparently, having reliable supplies (accuracy in terms of quantity), reasonable and competitive raw materials' prices, and consistent availability of day-old chick had been identified as the top three most important factors. The result, however, may not be generalizable due to small number of respondents. From all four selected respondents, only one stated that relationships were the most important factor when selecting potential integrator. It is therefore predicted that growers prefer a fully integrated partner that has both vertical and horizontal supply chain capabilities. Nonetheless, the extent of which a grower has actually had the luxury to 'select' reliable integrator instead of the integrator choosing its preferable grower remains debatable as the latter has more bargaining power (as well as resources). Hence, avenue for further research may include investigation over integrators' view for grower selection criteria. In terms of contribution, this study presented an attempt to establish a more holistic supply chain perspective of Malaysian local broiler industry. The study can also be generalized by getting more respondents from local broiler industry to participate in the survey. This may include key officers from both integrators and growers.

\section{References}

1. Ali, A. H. M., (2003). Poultry Industry in Malaysia: Issues and Challenges. Knowledge Transfer Programme (KTP) Workshop on Business Model for Broiler Industry in Malaysia. Penang.

2. Ariffin, Ahmad Shabudin Bin, Hendrik Lamsali, and ShahimiMohtar, (2013). 'Linkages between Integrator, Grower Involvement and Business Performance: An Excerpt from Preliminary Findings', International Journal of Supply Chain Management, 2.3: 47-52.

3. Ariffin, Ahmad Shabudin, Hendrik Lamsali, and ShahimiMohtar, (2012). 'Linkages between supplier, customer involvement and business performance: A green supply chain investigation in the poultry industry', 2012 International Conference on Green and Ubiquitous Technology (GUT), IEEE, Bandung, 41-44.

4. Febransyah, A., and Simangunsong, E., (2015). 'Supply chain competitiveness in food industry: An Indonesian case, Supply Chain Design and Management for Emerging Markets', Springer International Publishing, 147-175.

5. Garcia, R. G., Almeida Paz, I. C. L., Caldara, F. R., Nääs, I. A., Pereira, D. F., and Ferreira, V. M. O. S., (2012). 'Selecting the most adequate bedding material for broiler production in Brazil', RevistaBrasileira CiênciaAvícola, 14.2: 121-127.

6. Korpela, J., and Tuominen, M., (1996). 'A decision support system for strategic issues management of logistics', International journal of production economics, 46: 605-620.

7. Opasanon, Sathaporn, and PattarakamolLertsanti, (2013). 'Impact analysis of logistics facility relocation using the analytic hierarchy process (AHP)', International Transactions in Operational Research, 20.3: 325-339.

8. Saaty, T. L., (1979). Mathematical modeling of dynamic decisions; priorities and hierarchies with time dependence, Mathematics and computers in Simulation, 21.4: 352-358.

9. Saaty, T. L., (1990). 'How to make a decision: the analytic hierarchy process', European journal of operational research, 48.1: 9-26.

10. Saaty, T. L., (1994). 'Highlights and critical points in the theory and application of the analytic hierarchy process', European journal of operational research, 74.3: 426-447.

11. Saaty, T. L., (2008). 'Decision making with the analytic hierarchy process', International journal of services sciences, 1.1: 83-98. 
12. Saaty, T.L., (2000). 'Fundamentals of decision making and priority theory with the analytic hierarchy process', Rws Publications, 6.

13. Sipahi, Seyhan, and Mehpare Timor, (2010). 'The analytic hierarchy process and analytic network process: an overview of applications', Management Decision, 48.5: 775808.

14. Siqueira, K. B., da Silva, C. A. B., and Aguiar, D. R., (2008). 'Viability of introducing milk futures contracts in Brazil: a multiple criteria decision analysis', Agribusiness, 24.4: 491-509.

15. Vaidya, Omkarprasad S., and Sushil Kumar, (2006). 'Analytic hierarchy process: An overview of applications', European Journal of operational research, 169.1: 1-29.

16. Yakovleva, N., Sarkis, J., and Sloan, T., (2012). 'Sustainable benchmarking of supply chains: the case of the food industry', International Journal of Production Research, 50.5: 1297-1317. 